\title{
ヒト冠状動脈硬化の進展における膠原線維と 内膜平滑筋細胞の役割
}

池田 フミ* 吉田洋二** 田村康二*

\section{I. 目 的}

内膜平滑筋細胞の増殖は, 動脈硬化の成り立ちにおけ る key event として重要視されているが1), 一般にヒト の硬化巣においては，筋細胞の増殖よりも細胞間質のコ ラーゲンの増生が目立つ。

ヒトの冠状動脈は乳幼児期からびまん性内膜肥厚 (diffuse intimal thickening, DIT) を生じ2), 後にその一部 がさらに肥厚して偏心性内膜肥厚 (eccentric intimal thickening, EIT) となり ${ }^{3)}$ ，それはしばしば動脈硬化性丘状 内膜肥厚 (plaque) 一と移行すると考えられている4). そ こでわれわれは，ヒト冠状動脈における内膜の経年的肥 厚と Plaque の内膜組織成分の変化を比較し, 動脈硬化 の進展に及ぼす膠原線維と平滑筋細胞の役割を検討した。

\section{II. 研究症例と方法}

山梨医科大学附属病院および他施設において剖検され た新生児から 92 歳までの 253 症例 (男子 150 例, 女子 103 例) の冠状動脈を用いた (Table 1). 症例の主病理診 断は，悪性新生物 $62.4 \%$, 心疾患 $9.1 \%$ (先天性心疾患 $5.9 \%$, 弁膜症 $0.4 \%$, 特発性心筋症 $1.6 \%$, 心筋炎 $1.2 \%$, 脳血管障害 $2.4 \%$, 肺炎 $10.7 \%$, 肝硬変 $2.0 \%$, 腎炎 $0.8 \%$, 自己免疫疾患 $2.0 \%$ ，その他 $10.6 \%$ であった. 急性心笳 梗塞や家族性高脂血症など，高度な冠状動脈硬化を有す ると考えられる症例は, 動脈内膜の組織成分を強く変え る可能性があるので除外した.

冠状動脈右起始部 (Seg. 1) と，回旋枝分岐直後の前室 間枝 (Seg. 6) のそれぞれ中央部より，動脈を横断する組 織片を採取した (Fig. 1). これよりパラフィン切片を作 り, HE 染色, elastica-Masson's trichrome (EMT) 染色 を行った.

\section{* 山梨医科大学第二内科学教室}

** 同 第一病理学教室

原稿受取日：1991 年 7 月 19 日

採用決定日：1991 年 11 月 20 日
組織計測：各症例の Seg. 1 および Seg. 6 より DIT と EIT または Plaque を選び，それぞれの内膜肥厚 (内皮一 内弾性板間距離) を接眼マイクロメーターで計測した. DIT は動脈の心外膜側壁のびまん性内膜肥厚部を, EIT は，限局性に隆起した内膜肥厚部の最大肥厚部を測定し た (Fig. 1).また EIT のうち Atheroma や膠原線維の高 度な脂肪性膨化を伴っているものを Plaque とした. 内 膜肥厚計測部位での中膜の厚さを測定し, 中膜の厚さに 対する内膜肥厚度 $(\mathrm{I} / \mathrm{M}$ 比) を求めた.

20歳代以降の各症例について DIT, EIT または Plaque の $170 \mu \mathrm{m}$ 幅 (後二者については最大肥厚部) の内膜一断 面に含まれる平滑筋細胞, 血液由来細胞 (リンパ球, 単 球), 膠原線維, 弾性線維, 細胞外基質, および Atheroma の面積の内膜面積に対する割合を point counting 法で測 定した。20歳以前の若年者については，内膜肥厚が軽度 で測定に十分な point 数が得られなかったので除外した。 また測定範囲内に含まれる内膜平滑筋細胞数は全症例に ついて計測した．測定方法および検定法についての詳細 はすでに報告した ${ }^{4)}$.

免疫組織化学的検索：死後 4 時閒以内に剖検し得た症 例は，4\% paraformaldehyde (PFA) および冷アセトン固 定 (AmeX 法)によるパラフィン切片を作製した. 染色 には Anti muscle 抗体 (HHF35, Enzo Biochem. Inc., New York), Anti macrophage 抗体 (HAM56, Enzo Biochem. Inc.), Anti prolyl hydroxylase $\beta$ subunit 抗体 (富士薬品工業(秼), 高岡), Anti collagen type I, III, IV, V 抗体 (Southern Biotechnology Associates Inc., Birmingham, UK), Anti PCNA 抗体 (19F4 IgG $\kappa^{5)}$, 長崎大学医 学部第三解剖学教室, 中根教授より提供を受けた）を用 いて酵素抗体法 (PAP 法, ABC 法)を行った。

\section{III. 結 果}

\section{組織学的, 組織計測的研究}

1) DIT: Seg. 1, Seg. 6 ともに内膜の厚さは加齡に伴 い増加した（男子 Seg. $1 \mathrm{r}=0.738$, Seg. $6 \mathrm{r}=0.526$, 女子 
Table 1 The number of examined cases

Male

\begin{tabular}{ccrcrrr}
\hline \multirow{2}{*}{$\begin{array}{c}\text { Age } \\
\text { group }\end{array}$} & \multirow{2}{*}{$\begin{array}{c}\text { Total } \\
\text { cases }\end{array}$} & \multicolumn{2}{c}{ Seg. 1 } & & \multicolumn{2}{c}{ Seg. 6 } \\
\cline { 3 - 4 } \cline { 5 - 6 } & & EIT & Plaque & & EIT & Plaque \\
\hline 0 & 16 & 14 & 0 & & 14 & 0 \\
1 & 8 & 8 & 0 & 7 & 0 \\
10 & 12 & 12 & 0 & 12 & 0 \\
20 & 12 & 10 & 1 & & 10 & 1 \\
30 & 10 & 9 & 2 & 8 & 2 \\
40 & 18 & 14 & 4 & 14 & 2 \\
50 & 20 & 16 & 4 & 14 & 6 \\
60 & 21 & 15 & 6 & 14 & 6 \\
70 & 20 & 7 & 10 & 8 & 10 \\
80 & 13 & 6 & 6 & 5 & 8 \\
\hline Total & 150 & 111 & 33 & 106 & 35 \\
\hline & & & & & (cases)
\end{tabular}

Female

\begin{tabular}{ccccccc}
\hline \multirow{2}{*}{$\begin{array}{c}\text { Age } \\
\text { group }\end{array}$} & \multirow{2}{*}{$\begin{array}{c}\text { Total } \\
\text { case }\end{array}$} & \multicolumn{2}{c}{ Seg. 1 } & & \multicolumn{2}{c}{ Seg. 6 } \\
\cline { 5 - 6 } & & EIT & Plaque & EIT & Plaque \\
\hline 0 & 22 & 16 & 0 & 21 & 0 \\
1 & 8 & 7 & 0 & 8 & 0 \\
10 & 6 & 6 & 0 & 6 & 0 \\
20 & 7 & 7 & 0 & 7 & 0 \\
30 & 10 & 10 & 0 & 9 & 1 \\
40 & 10 & 9 & 1 & 9 & 1 \\
50 & 10 & 7 & 3 & 8 & 2 \\
60 & 10 & 5 & 5 & 2 & 6 \\
70 & 10 & 5 & 5 & 3 & 7 \\
80 & 10 & 3 & 6 & 1 & 9 \\
\hline Total & 103 & 75 & 20 & 74 & 26 \\
\hline & & & & & (cases)
\end{tabular}
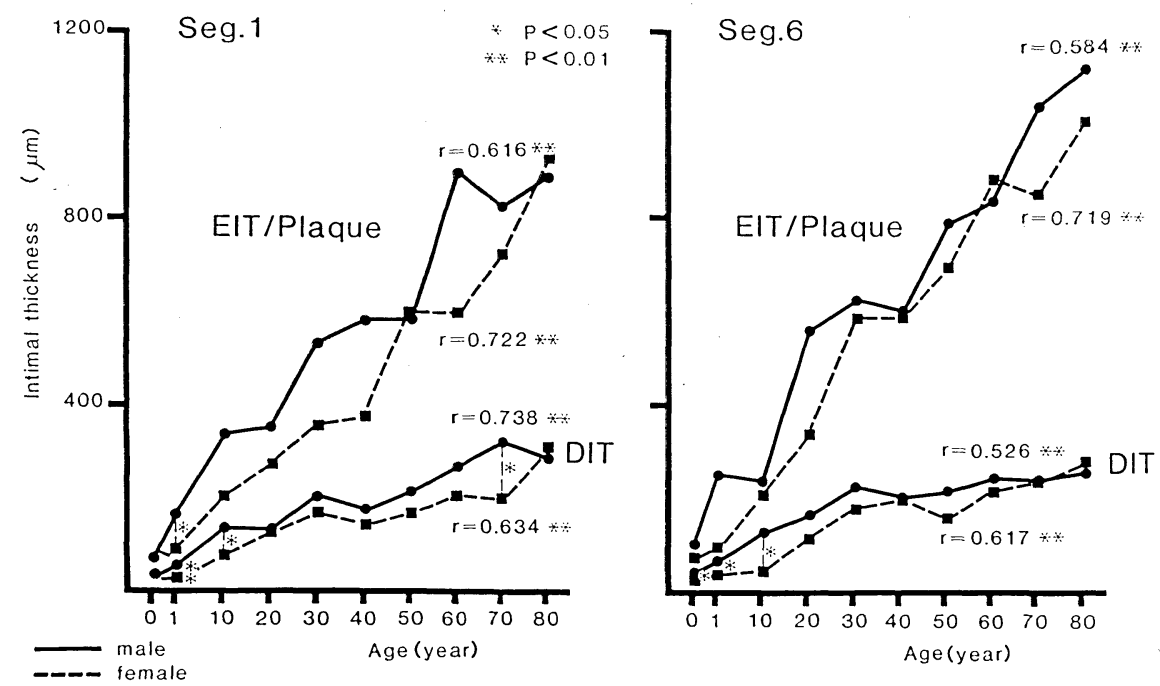

Fig. 2 Intimal thickness in segments 1 and 6 of the coronary artery in each decade. Comparison was made between male and female.

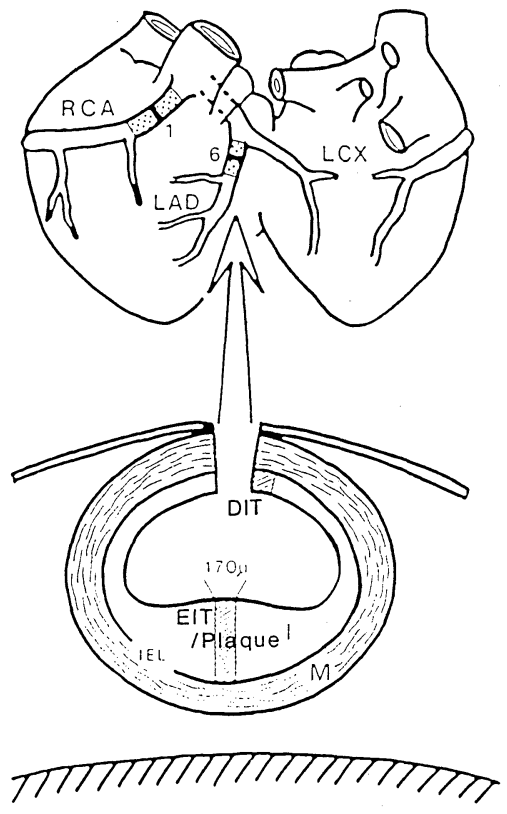

Fig. 1 A scheme of the tissue preparation for microscopic examinations. D: diffuse intimal thickening. EIT/Plaque: eccentric intimal thickening or plaque. I: intima. IEL: internal elastic lamina. $\mathrm{M}$ : media. RCA: right coronary artery. LAD: left anterior descending artery. LCX: left circumflex artery. 1: segment 1. 6: segment 6 . : areas of segment. $\square$ : sections investigated histometrically and immunohistochemically. areas investigated histometrically. 
Table 2 The number of smooth muscle cells and I/M ratios in diffuse and eccentric intimal thickening of the coronary artery in each decade

Male

\begin{tabular}{|c|c|c|c|c|c|c|c|c|c|}
\hline \multirow{3}{*}{ Age } & & \multicolumn{4}{|c|}{ SMC No. } & \multicolumn{4}{|c|}{$\mathrm{I} / \mathrm{M}$} \\
\hline & & \multicolumn{2}{|c|}{ Seg. 1} & \multicolumn{2}{|c|}{ Seg. 6} & \multicolumn{2}{|c|}{ Seg. 1} & \multicolumn{2}{|c|}{ Seg. 6} \\
\hline & & Mean & $\mathrm{SD}$ & Mean & SD & Mean & $\mathrm{SD}$ & Mean & SD \\
\hline \multirow[t]{10}{*}{ DIT } & 0 & 6.9 & $12.8 * * *$ & 28.7 & $44.8^{*}$ & 0.27 & $0.19 * *$ & 0.48 & $0.36^{* *}$ \\
\hline & 1 & 20.0 & $8.4^{* *}$ & 47.3 & 26.9 & 0.50 & $0.13 * *$ & 0.62 & $0.36^{*}$ \\
\hline & 10 & 49.9 & 45.9 & 66.6 & 30.7 & 0.74 & $0.31 *$ & 0.75 & $0.58^{*}$ \\
\hline & 20 & 41.6 & $16.9 *$ & 65.9 & 60.7 & 0.80 & 0.50 & 0.92 & 0.77 \\
\hline & 30 & 69.8 & 12.6 & 70.8 & 23.6 & 1.13 & 0.50 & 1.11 & 0.49 \\
\hline & 40 & 53.6 & 18.9 & 50.1 & $19.1^{*}$ & 0.71 & 0.29 & 0.93 & 0.45 \\
\hline & 50 & 53.4 & 20.4 & 61.8 & 17.1 & 1.07 & 0.52 & 1.05 & 0.52 \\
\hline & 60 & 63.1 & 20.6 & 55.1 & 31.9 & 1.20 & 0.89 & 1.09 & 0.71 \\
\hline & 70 & 57.6 & 20.1 & 50.5 & $23.7^{*}$ & 1.83 & 1.23 & 1.13 & 0.56 \\
\hline & 80 & 50.4 & 18.9 & 48.2 & 26.8 & 1.25 & 0.71 & 1.10 & 0.90 \\
\hline EIT/ & 0 & 27.7 & $41.1 * * *$ & 92.3 & $55.5 * *$ & 0.73 & $0.66 * *$ & 1.29 & $1.71^{* *}$ \\
\hline \multirow[t]{9}{*}{ Plaque } & 1 & 73.0 & $32.8^{*}$ & 119.2 & 87.9 & 1.79 & 1.52 & 1.58 & 1.67 \\
\hline & 10 & 72.3 & $36.2^{*}$ & 157.9 & 67.8 & 1.68 & 1.42 & 1.56 & 0.95 \\
\hline & 20 & 97.3 & 35.5 & 157.9 & 108.0 & 2.30 & 1.82 & 4.22 & 4.91 \\
\hline & 30 & 124.0 & 46.9 & 135.8 & 56.4 & 2.70 & 1.37 & 3.42 & 3.51 \\
\hline & 40 & 111.8 & 51.9 & 126.1 & 51.0 & 2.39 & 1.07 & 3.22 & 2.09 \\
\hline & 50 & 110.4 & 56.3 & 107.5 & 25.4 & 3.51 & $2.37 *$ & 6.88 & 11.5 \\
\hline & 60 & 124.7 & 50.1 & 110.7 & 54.6 & 5.25 & $4.74 * *$ & 5.21 & 4.51 \\
\hline & 70 & 82.1 & $16.7^{*}$ & 99.4 & 53.1 & 5.59 & $3.03 * *$ & 6.73 & $5.15^{*}$ \\
\hline & 80 & 96.6 & 47.5 & 71.4 & 45.9 & 4.96 & $3.53 * *$ & 8.37 & $5.40^{* *}$ \\
\hline
\end{tabular}

Female

\begin{tabular}{|c|c|c|c|c|c|c|c|c|c|}
\hline \multirow{3}{*}{ Age } & & \multicolumn{4}{|c|}{ SMC No. } & \multicolumn{4}{|c|}{$\mathrm{I} / \mathrm{M}$} \\
\hline & & \multicolumn{2}{|c|}{ Seg. 1} & \multicolumn{2}{|c|}{ Seg. 6} & \multicolumn{2}{|c|}{ Seg. 1} & \multicolumn{2}{|c|}{ Seg. 6} \\
\hline & & Mean & SD & Mean & $\mathrm{SD}$ & Mean & SD & Mean & SD \\
\hline \multirow[t]{10}{*}{ DIT } & 0 & 3.6 & $6.2 * * *$ & 2.2 & $3.9 * * *$ & 0.27 & $0.11^{* *}$ & 0.34 & $0.34 * *$ \\
\hline & 1 & 6.4 & $4.9 * * *$ & 10.9 & $8.3 * * *$ & 0.17 & $0.08 * *$ & 0.25 & $0.12 * *$ \\
\hline & 10 & 28.8 & $11.2^{*}$ & 16.3 & $10.2 * *$ & 0.42 & $0.18^{*}$ & 0.78 & $0.55^{* *}$ \\
\hline & 20 & 39.9 & 19.7 & 40.9 & 24.3 & 0.64 & 0.31 & 0.69 & 0.34 \\
\hline & 30 & 62.5 & 26.7 & 65.3 & 29.3 & 1.03 & 0.72 & 1.27 & 0.65 \\
\hline & 40 & 51.2 & 19.6 & 68.5 & 27.4 & 0.67 & 0.27 & 1.38 & 1.24 \\
\hline & 50 & 44.7 & 19.5 & 40.9 & $18.2^{*}$ & 0.75 & 0.47 & 1.03 & 0.90 \\
\hline & 60 & 75.1 & 30.4 & 65.3 & 36.8 & 0.98 & 0.36 & 0.97 & 0.54 \\
\hline & 70 & 49.7 & 18.6 & 55.1 & 25.8 & 1.07 & 0.73 & 1.39 & 0.77 \\
\hline & 80 & 60.4 & 25.1 & 47.9 & 20.9 & 1.56 & 0.94 & 0.81 & 0.48 \\
\hline EIT/ & 0 & 32.9 & 39.2 & 28.4 & $31.1 * *$ & 0.84 & $0.97 * *$ & 1.03 & $0.94 * *$ \\
\hline \multirow[t]{9}{*}{ Plaque } & 1 & 27.6 & 14.5 & 46.9 & $20.4 * *$ & 0.52 & $0.19^{* *}$ & 0.81 & $0.29 * *$ \\
\hline & 10 & 61.0 & 32.0 & 85.5 & 46.2 & 1.25 & $0.66^{*}$ & 1.66 & 0.65 \\
\hline & 20 & 85.9 & 51.7 & 104.9 & 65.7 & 1.51 & 0.63 & 2.11 & 1.05 \\
\hline & 30 & 115.3 & 26.9 & 129.9 & 57.9 & 1.91 & 0.71 & 3.30 & 3.48 \\
\hline & 40 & 115.5 & 52.0 & 124.7 & 42.8 & 2.06 & 0.93 & 2.84 & 1.30 \\
\hline & 50 & 106.2 & 45.7 & 120.2 & 44.9 & 3.31 & 4.25 & 3.15 & 2.41 \\
\hline & 60 & 138.4 & 58.1 & 121.8 & 32.2 & 3.12 & $1.67^{*}$ & 4.80 & $2.75^{*}$ \\
\hline & 70 & 109.6 & 43.7 & 105.0 & 34.9 & 7.70 & $8.89 * *$ & 4.82 & $2.25^{*}$ \\
\hline & 80 & 76.8 & $21.5^{*}$ & 100.8 & 29.2 & 6.04 & $4.75^{* *}$ & 9.10 & $7.23 * *$ \\
\hline
\end{tabular}

vs. Age $30 \mathrm{p}<0.05^{*}, 0.01^{* *}, 0.001^{* * *}$ 


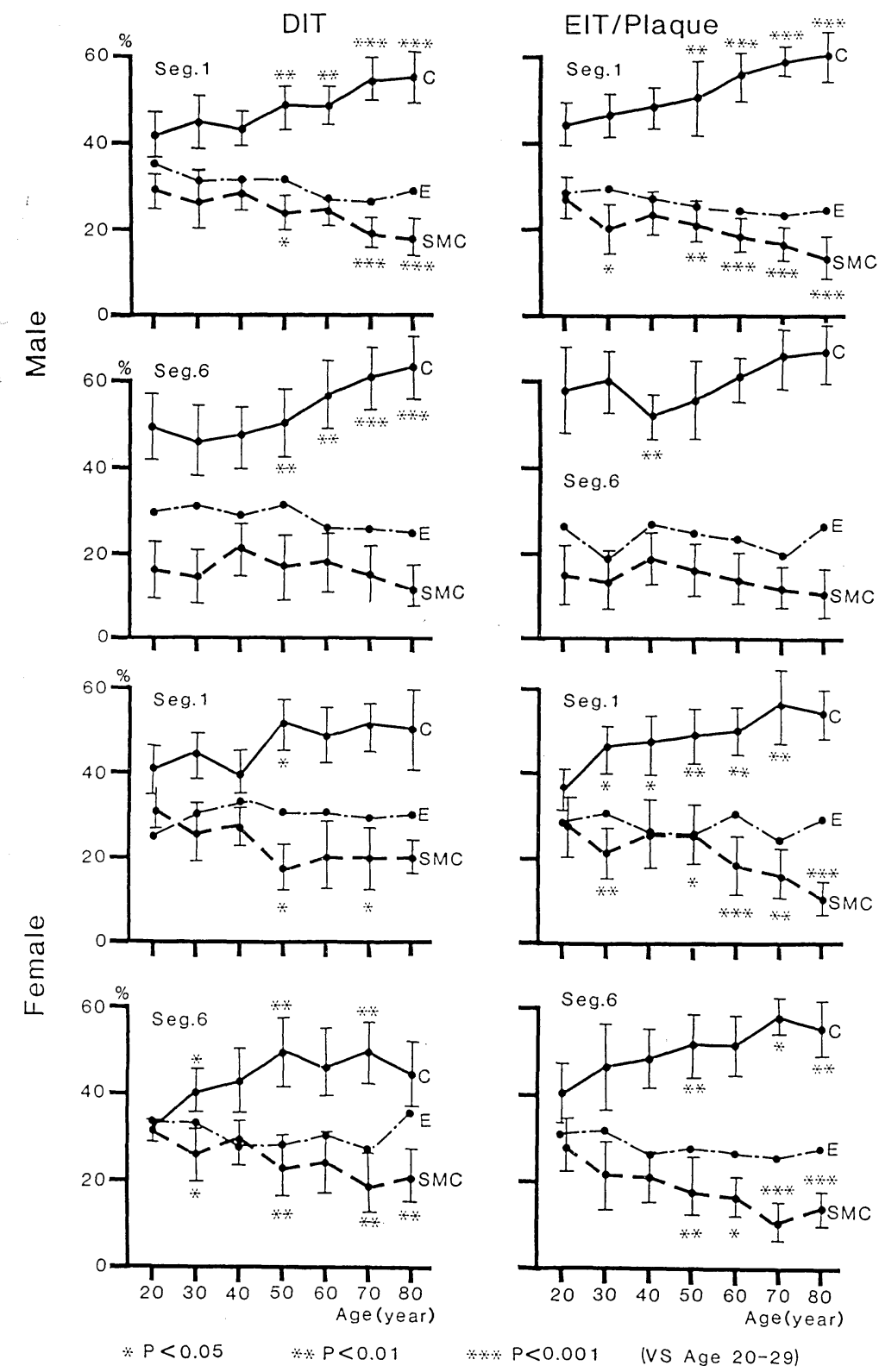

Fig. 3 Chronological changes of volume fractions of histological components in intimas of segments 1 and 6 of the coronary artery. C: Collagen fiber. E: Elastic fiber. SMC: Smooth muscle cell.

Seg. $1 \mathrm{r}=0.634$, Seg. $6 \mathrm{r}=0.617, \mathrm{p}<0.01$, Fig. 2). 内膜 肥厚について Segment 間で有意な差はなかったが，性 差を検討すると，高齢者を除いて男子が女子を上回り， Seg. 1 において 1 歳代, 10 歳代, 70 歳代で, Seg. 6 で は 0 歳代, 1 歳代, 10 歳代で有意であった $(\mathrm{p}<0.05)$. 中膜の厚さは30歳代まではほぼ横ばいであった。 中膜の 厚さに対する内膜肥厚の割合 (I/M 比)をみると, 30 歳 代までは加龄とともに堌加し，30歳で 1 を超えたが，そ の後増加しても 2 以上にはならなかった (Table 2).

いずれの年代においても膠原線維 (EMT 染色で緑色
に染まる線維成分）は内膜の主たる組織成分であった. 内膜に占める膠原線維の割合は, 男子例では50歳代以後 に経年的な増加を示した (Seg. $1 \mathrm{r}=0.635, \mathrm{p}<0.01$, Seg. $6 \mathrm{r}=0.544, \mathrm{p}<0.05$, Fig. 3). 女子では 40 歳代から 50 歳 代にかけてその割合は有意に増加したが，その後はほぼ 横ばいの状態であった. 20歳代の内膜の成分比を基準と して，各年代における成分比を検討すると，男女とも50 歳以降で膠原線維は有意に増加していた $(\mathrm{p}<0.01)$. 内膜 の膠原線維は太い束状の線維と繊細な線維より成るが, 加齢とともに，また平滑筋細胞の減少とともに束状の線 

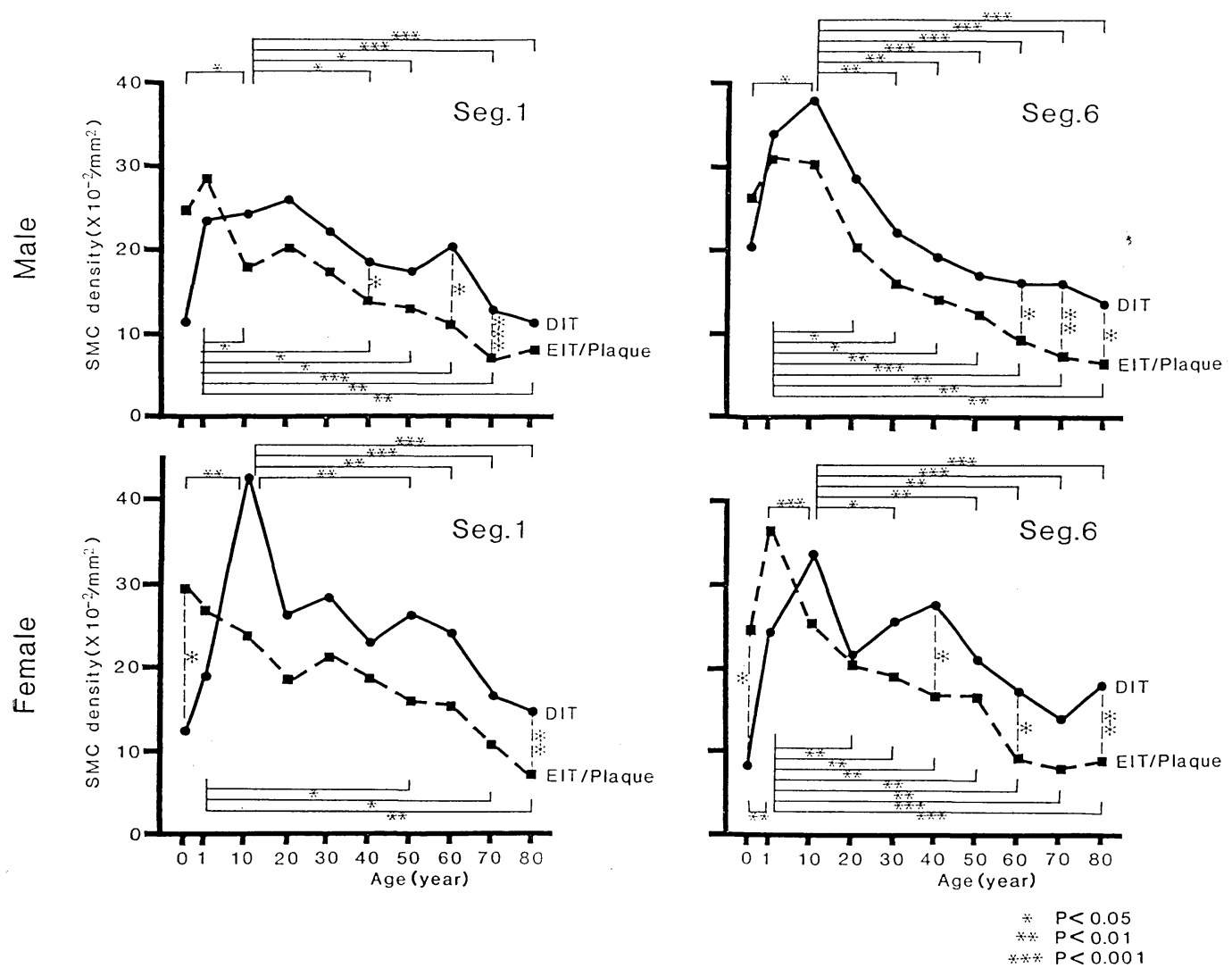

Fig. 4 Chronological changes of SMC density and I/M ratios in intimas of segments 1 and 6 of the coronary artery.

維が増加した．平滑筋細胞の割合は 50 歳代以降で有意な 減少を認めた. DIT 測定部位の幅 $170 \mu \mathrm{m}$ の内膜全層の 平滑笳細胞の絶対数は 30-40 歳代までは増加していたが, その後は大きな変化を示さなかった (Table 2). 平滑筋細 胞密度 (細胞数/面積) は男女とも 10 歳代でピークを示 し(ただし男子の Seg. 1 では 20 歳代)，40歳代以降で有 意に減少していた $(\mathrm{p}<0.01$, Fig. 4). 弾性線維 (EMT 染 色で濃紫色に染まる線維) は加齡とともに減少する傾向 を示し，また内弾性板は断裂し不明瞭となった．細胞外 基質 (EMT 染色で淡灰緑色, alcian 青染色陽性の細胞 外均質性物質）は高齢になると減少した。血液由来細胞 （リンパ球，単球）は幼少児期より内膜表層に認められた が，高龄者では泡沫細胞が増加していた。

2) EIT: 両 Segment ともに EIT の内膜肥厚は全ての 年代に打いてDITより有意に厚く，その経年的増大は 急峻であった. 各年代における肥厚の程度も Segment 間, 男女間に有意な差は認められなかったが，一般に Seg. 6 の内膜肥厚は Seg. 1 よりも強い傾向があった (Fig. 2).

EIT の中膜の厚さは，50 歳代までは DIT 下の中膜と同 様であったが，60 歳代以降では DIT 下の中膜に比べ菲 薄となった． I/M 比は幼少児期より 1 以上の值をとり，
経年的に増加したが， 60 歳代以降で著増した $(\mathrm{p}<0.01$ ， Table 2).

EITにおいても膠原線維が主たる組織成分であり，男 女とも 50 歳代以降で 20 歳代に比較して有意に増加をし ていた (Fig. 3). DIT に比べ EIT の膠原線維の割合は大 きい傾向にあり, 高度の病変を示す EIT では硝子化した 膠原線維や膨化膠原線維が増加していた。平滑筋細胞数 はDITょり多く, 30 歳代までは増加し, それ以降は横 ばいであったが，平滑筋密度は 1 歳代から経年的に減少 し( $<<0.05$, Fig. 4), 10 歳代からは DIT よりも小さく なり，60 歳代以降では DIT に比べて有意に減少してい る場合が多かった．平滑筋細胞の割合は，男子の Seg. 6 を除き，加齢とともに有意に減少していた $(\mathrm{p}<0.01$, Fig. 3). 弾性線維は男子の Seg. 1, 女子の Seg. 6 において, 加齢的に減少する傾向にあった．細胞外基質は50歳代以 降で男女ともに減少していた. 血液由来細胞は 0 歳代よ り, 泡沫細胞は 10 歳代よりみられ, DITよりも多く出 現していた。

3) Plaque: Plaque は, 男子では 20 歳代から, 女子 では 30 歳代から認められた. Plaque と EIT とを分けて 比較すると, 内膜肥厚は Plaque の方が強く (70, 歳代男 


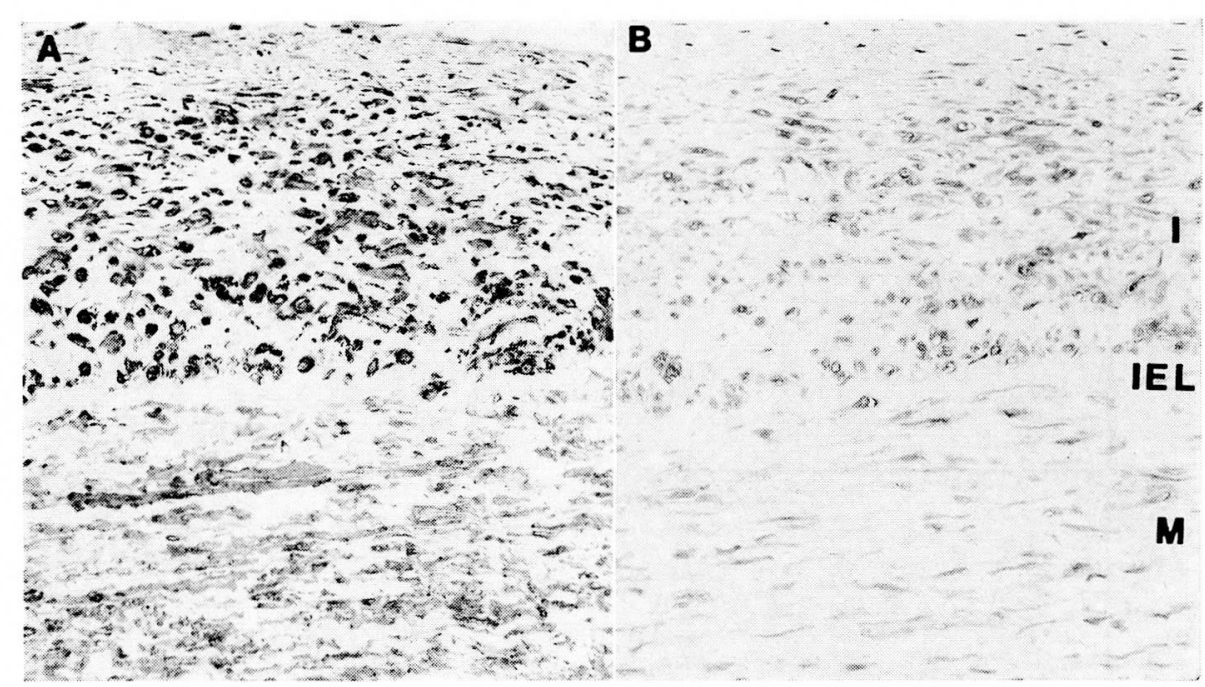

Fig. 5 Immunohistochemical staining with $\operatorname{HHF} 35(\mathrm{~A})$ and prolyl hydroxylase (B) in DIT of seg. 6. Intimal smooth muscle cells are more strongly stained than medial smooth muscle cells. I: intima. IEL: internal elastic lamina. $\mathrm{M}:$ media. (48 yrs, male, $\times 125)$

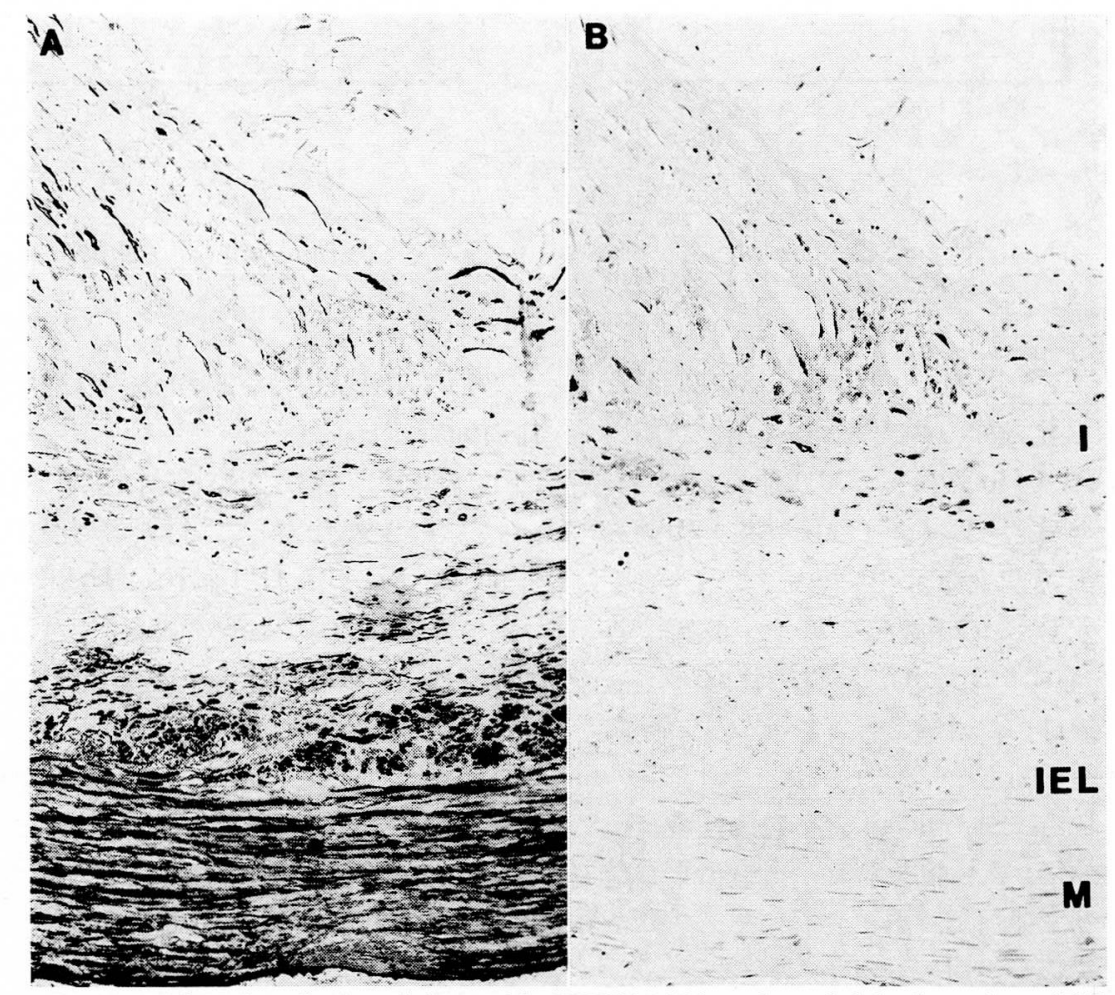

Fig. 6 Immunohistochemical staining with $\operatorname{HHF} 35(\mathrm{~A})$ and prolyl hydroxylase $(\mathrm{PH}, \mathrm{B})$ in a plaque of seg. 6. A : Intimal elongated SMCs are strongly stained, but stellar cells weakly. B: Intimal smooth muscle cells show positive reaction to anti $\mathrm{PH}$ antibody. $\mathrm{I}$ : intima. IEL: internal elastic lamina. $\mathrm{M}$ : media. (76 yrs, male, $\times 125)$

子の Seg. 1 では EIT: $641 \mu \mathrm{m}$, Plaque: $1,067 \mu \mathrm{m}), \mathrm{I} / \mathrm{M}$ 比もより高值であった (70 歳代男子の I/M 比は EIT: 4.1, Plaque: 7.8). 内膜平滑筋細胞数は, 密度とともに EITよりも低い值であった.

\section{免疫組織化学的研究}

1) 細胞成分

内膜に存在する紡錘形細胞のほとんど全ては HHF35 抗体に陽性であり, 泡沫細胞の一部も陽性に染まった。 


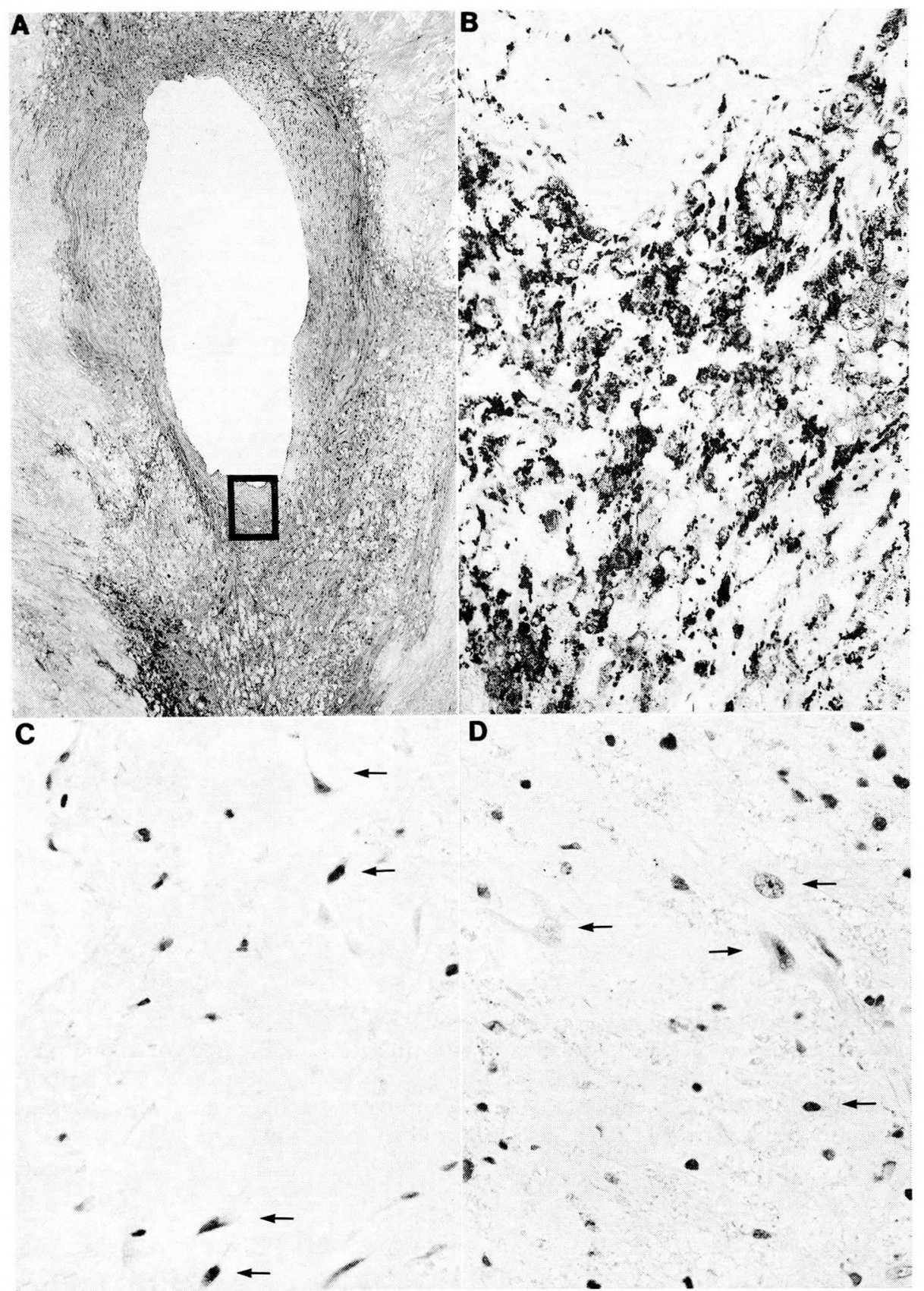

Fig. 7 Plaque with macrophage infiltlation and neovascularization ( $76 \mathrm{yrs}$, male). A: HE stain $\times 40$. B: Immunohistochemical staining with prolyl hydroxylase antibody in an area framed in $A \times 200$. C and D: Immunohistochemical staining with anti PCNA antibody (C: upper area, D: middle area of the intima, Arrows designate positive cells. $\times 400)$.

HAM56 抗体陽性細胞は 2 歳の症例から認められ, EIT では内膜表層に, Plaque では Atheroma の周囲, 特に Plaque から DIT へ移行する部分の Plaque shoulder に 多数認められた. HAM56 抗体陽性細胞の多くは脂質を 貣食した泡沫細胞であったが，泡沫細胞間に浸潤する単 核細胞も陽性であった。
Prolyl hydroxylaase (PH) 抗体陽性細胞 は外膜と内膜 に主として存在し, DIT では内膜の弾性筋性層の細胞と 結合織層の紡鍾形細胞に陽性であった (Fig. 5). Plaque の内膜では Atheroma 周囲の紡錘形細胞のほか, 泡沫細 胞の一部にも陽性で, Atheromaを覆う細胞線維性組織 (Fibrous cap) 内の大型の紡錘形ないし棈円形細胞に強 


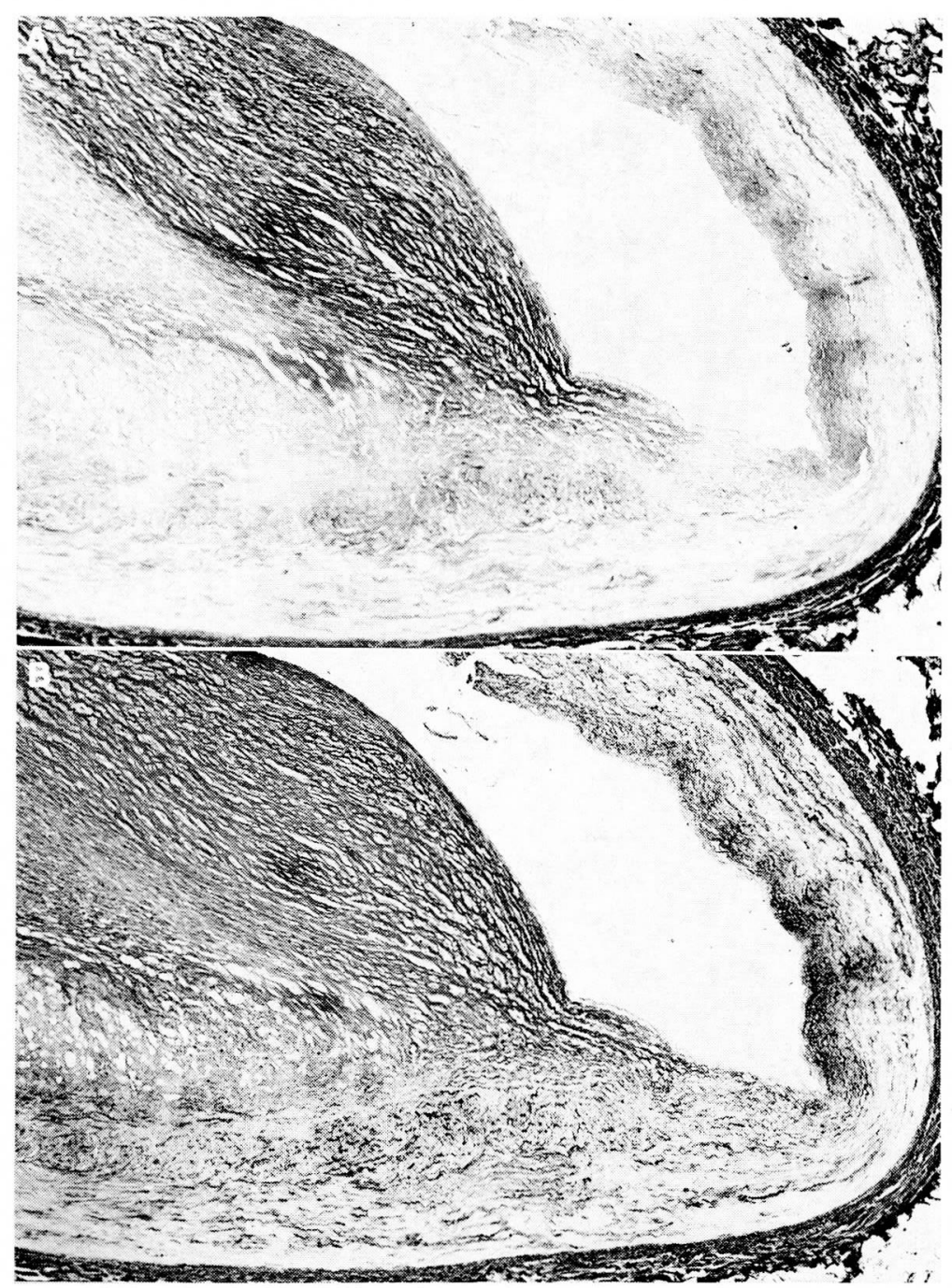

Fig. 8 Immunohistochemical staining with anti collagen type I antibody (A) and type III antibody (B). Anti type I collagen antibody reacts most strongly with collagen fibers in the fibrous cap of a plaque, although anti type III collagen antibody reacts equally with collagens in EIT, DIT and media. (46 yrs, male, $\times 60$ )

陽性であった (Fig. 6).

PCNA 抗体陽性細胞は DIT 部位に少なかったが，中 膜に比べ内膜に陽性細胞が多く存在した。 また若年者は 高齢者よりも陽性細胞数が多かった. Plaque では, 泡沫 細胞の浸潤部あるいはその付近に存在する紡鍾形ないし 不正多角形の内膜細胞の核が多数陽性に染まっていた (Fig. 7). Atheroma 下の中膜の泡沫細胞浸潤部周囲には 他の部位よりも陽性中膜筋細胞が多かった。そのほか, 内膜や中膜に新生した毛細血管の内皮細胞にも陽性細胞 が認められたが，固有冠状動脈の内皮細胞には陽性細胞 は少なかった。

2) 細胞間質

抗 Type I Collagen 抗体：陽性線維は DIT や中膜に
少なく, EIT, Plaque では陽性線維が多量に認められた。 特に Fibrous cap では陽性線維が太く束状, 緻密に存在 し, Atheroma 内の膨化または崩壊した線維の同抗体に 対する染色性は著しく減少していた (Fig. 8).

抗 Type III Collagen 抗体: 陽性線維は DIT, EIT, Plaque の内膜および中膜に一様に存在し，特に内膜に多 量に存在することはなかった. Atheroma 内の膨化線維 や断片化した膨化膠原線維内の踈開した細線維も陽性に 染まった (Fig. 8).

抗 Type IV Collagen 抗体: 内皮直下と平滑筋細胞周 囲の基底膜が染まった。 また Atheroma 内にも断片化し た陽性線維が散在していた。

抗 Type V Collagen 抗体 : 筋細胞周囲の基底膜に接し 
た間質に繊細に染色され, 中膜や内膜の表層よりも内膜 の弾性筋性層に強く染色された. Fibrous cap や Atheroma 内の間質には少ないが, Shoulder や Fibrous cap 内の平滑筋細胞の細胞間質にも陽性反応がみられた.

\section{IV. 考察}

ヒトの冠状動脈は他の臓器動脈とは異なり, 出生直後 にすでにびまん性内膜肥厚 (DIT) が認められる ${ }^{6)}$. DIT の成り立ちを組織学的に観察すると, まず中膜筋細胞が 内弾性板を断裂, 重複化しながら内膜に侵入し, 内膜内 で増殖して多層化した弾性板とともに弾性筋性層を形成 する.さらに弾性筋性層の筋細胞は内皮下に遊走, 増殖 し，基質の多い結合織層を作り，DIT は形成される. DIT は加齢とともに肥厚し，中膜の厚さを上回るが，40 歳代以後ではほぼ一定で, 平均 $400 \mu \mathrm{m}$ を超えることは なく，また I/M 比もほぼ一定であった.したがって DIT は中膜の発育とともに肥厚するので, 生理的内膜肥厚と 理解することができる.

偏心性内膜肥厚 (EIT) は, 一般に心筋層側の壁に生じ る.心筋層側は冠状動脈の内湾側にあたり，血流速度勾 配は筋層側で減少し7)，血流の淀みや乱れを生ずるため に，低ずり応力部位であると考えられる ${ }^{8)}$.このため内 皮細胞の透過性は六進し, 内膜肥厚が増強すると考えら れている.それを裏づける所見として EIT の形成の初期 には結合織層の表層に内膜水腫が形成され, しばしばリ ンパ球ないし単球様の細胞浸潤がみられる. EIT は加齢 とともに急速に厚さを増し, その厚さが $500 \mu \mathrm{m}$ 以上に なると内膜の中層から深層の膠原線維が脂肪性に膨化し， その中心が壊死に陷り, Atheroma が形成される.した がって EITは粥状硬化の前段階と考えられる.

膠原線維は20歳以上のいずれの年代においても内膜の $40 \%$ 以上を占め, 最大の内膜成分であり, 加齢とともに 増加した. 一方平滑筋細胞の割合は, 若年者に多く, 加 齢とともに減少する傾向にあった．20歳以下の若年者の 内膜を組織学的に観察すると, 中高齢者に比較して平滑 笳細胞が多く, 平滑筋細胞密度も高かった. 以上の成績 から, DIT, EIT ともに内膜肥厚の初期には平滑筋細胞 の増殖が肥厚の増大に主要な役割を演じるが，50歳以上 になると20歳代に比べて有意に膠原線維が増加し, 膠原 線維により内膜肥厚が増強すると考えられた.

内膜平滑筋細胞は形態的に一様でなく, 紡錘形のきわ めて細長い細胞から, 細胞質の大きな星状細胞が存在す る. 電顕的に前者は microfilament の多い細胞で, 粗面 小胞体や mitochondria の乏しい収縮型 (contractile) 平 滑筋細胞, 後者 (大きな星状細胞) は microfilament に泛 しく, 粗面小胞体や mitochondria が多く, Golgi 装置の
発達した細胞で, 合成型 (synthetic) 平滑筋細胞と一致す る.

Prolyl hydroxylase $(\mathrm{PH})$ は，コラーゲン合成細胞のマ 一カーとして用いられているので9), これを用いてコラ ーゲン合成細胞の有無と局在を検討した。 ヒトの冠状動 脈内膜においては PH は, 主に HHF35 抗体に弱陽性ま たは院性の大型細胞と, HHF35 抗体陽性の紡錘形細胞 の一部にもよく染め出された. したがって内膜の膠原線 維は主として内膜平滑筋細胞により産生されたものであ ることが強く示唆された. コラーゲンを合成している平 滑筋細胞は $\alpha$ アクンが減少しているといわれているの で ${ }^{10)}$ ，筋細胞由来の単クローン抗体 HHF3511) に対する 反応性が低下していると考えられる.この HHF35 抗体 に弱陽性または陰性で, かつ PH 陽性の星状大型細胞は 合成型平滑筋細胞で, HHF35 抗体, PH 抗体ともに陽 性の紡錘形細胞は，収縮型と合成型の性格を備えた中間 型細胞であろう.

抗 PCNA 抗体を用い, 増殖内膜細胞の同定を試み た. PCNA は late G1 から S 期に出現する核内蛋白で ある ${ }^{12,13)}$. PCNA をパラフィン切片上で免疫組織化学 的に証明することは困難ではあるが，きわめて早期 (死 後 2 時間以内）に $4 \%$ PFA に固定し得た 13 症例に限り 染色可能であった. 胎児, 新生児の DIT の内膜平滑筋 細胞, Plaque 内で泡沫細胞や新生毛細血管が出現してい る部位の平滑筋細胞が PCNA 染色に陽性に染まった. また中膜に泡沫細胞が浸潤している場所では, その周囲 の中膜細胞も陽性に染まった. 陽性細胞の核や細胞質の 形状はさまざまであったが，大型で不正多角形の細胞質 を有する細胞 (HHF35 に弱陽性または陰性) には陽性率 が高かった. 近年 in situ hybridizationを用いて組織切 片上での成長因子の mRNAの検出がなされており, mesenchymal-appearing intimal cells (MIC 合成型平滑筋 細胞に一致する), 特に星状細胞に PDGF mRNA は強 く認められ，この細胞はHHF35, HAM56 いずれも陰 性であるといわれている ${ }^{14)}$. 合成型平滑筋細胞は PDGF を産生すると同時に PDGF 受容体を有し14), PDGF 刺激により増殖するので, PDGF mRNA 発現細胞と PCNA 陽性細胞はかなり一致する可能性がある.しかし 本研究においては明らかにされなかった。

内膜に存在する膠原線維は I, III, IV, V, VI 型で, 動 脈硬化巣で増加する分子種には諸説があり, 生化学的な 分析により I 型が III 型に比較し増加するという報告15) と, I 型と III 型の比率に有意な変化はないが, $\mathrm{V}$ 型コ ラーゲンが増加するという報告がある ${ }^{16,17)}$. 冠状動脈内 膜の検索では, I 型コラーゲンは内膜の太い硝子化した 線維に陽性であり, 中膜や弾性筋性層には少なく, DIT 
よりもEIT または Plaque に多く認められた. III 型コ ラーゲンはI型コラーゲンと共存し, より細い線維に陽 性であったが，内膜および中膜にびまん性に分布してい た.

PDGF はコラーゲンの合成と崩壊を亢進する. 血管平 滑筋細胞ではないが, PDGF の刺激により, 線維芽細胞 は III, IV , V 型コラーゲンを産生するといわれている ${ }^{18)}$. 内膜のコラーゲンは筇細胞の増殖にさまざまな影響を 与える.すなわち I 型コラーゲンは筋細胞の増殖を促し, III 型は細胞型を合成型から収縮型へと変え, 筋細胞の DNA 合成を低下させることが知られている ${ }^{19)}$. V 型コ ラーゲンの作用としては, 細胞の表面ないし他のコラー ゲン線維の周囲に存在し接着の役割を示す ${ }^{20)}$ とともに, 筋細胞の遊走, 増生を促進するといわれている ${ }^{17)}$. 血管 平滑筋細胞と細胞間質ことにコラーゲンの相互作用はし だいに明らかにされつつある.動脈硬化を進行させるコ ラーゲンの増生の機序, 筋細胞の代謝に及ぼすコラーゲ ンの影響についての研究は今後の大きな課題であろう.

\section{V. 結 語}

1) ヒト冠状動脈のびまん性内膜肥厚 (DIT) は加齢と ともに増強したが, 生理的内膜肥厚と考えられる. 冠状 動脈の心筋付着側に DIT を場として限局性内膜肥厚 (EIT) が形成され, それは加齢とともに増強し, 弹状硬 化性病変が加わり Plaque に移行した。 したがって EIT は前硬化性病変と考えられた。

2) ヒト冠状動脈の内膜肥厚は, 若年者 (30 歳以下) においては内膜筋細胞の増殖が主体であったが，青年期 より間質結合織ことにコラーゲン線維の増生によって増 悪する.

3) DIT, EIT, Plaque の浅層や Plaque 辺縁の平滑筋 細胞には, 筋細胞特異抗体が弱陽性ないし陰性で, Prolyl hydroxylase 抗体陽性の細胞が存在した. Plaque の泡沫 細胞や新生毛細血管周囲には PCNA 抗体陽性の内膜細 胞が存在した.

4) I 型コラーゲン抗体は EIT, Plaque の肥厚内膜, あるいは Atheroma, Fibrous cap の線維と強く反応し, III 型コラーゲン抗体は内, 中膜の線維とびまん性に反 応した. $V$ 型コラーゲンは肥厚した内膜の弾性笳性層に 強く染まった。

謝辞：稿を終えるにあたり, 抗 PCNA 抗体を提供下 さった長崎大学医学部第三解剖 中根一穂教授に深謝す る。剖検症例の検索を㧍許し下さった埼玉県立小児医療 センター 小松明男先生, 信州大学医学部第一病理 重松 秀一教授, 第二病理 発地雅夫教授, 日本大学医学部第
二病理 桜井勇教授に深謝する．また，標本作製にご協 力いただいた山梨医科大学第一病理 岩戸忠, 清水三恵, 本田知子の諸氏に感謝する.

\section{文献}

1) Schwartz, S. M., Campbell, G. R. and Campbell, J. H.: Replication of smooth muscle cell in vascular disease. Circ. Res., 58: 427-444 (1986).

2) Velican, C. and Velican, D.: Some particular aspects of the microarchitecture of human coronary arteries. Atherosclerosis, 33: 191-200 (1979).

3) Stary, H. C.: Macrophages, macrophage foam cells, and eccentric intimal thickening in the coronary arteries of young children. Atherosclerosis, 64: 91108 (1987).

4) 五十嵐朋子, 池田フミ，高 緒蘭，三俣昌子，吉田 洋二：ヒ下冠状動脈のび漫性および偏心性内膜肥厚 の組織成分の变化一一第 1 報. 動脈硬化, 18: 11631172 (1990).

5) Ogata, K., Kurki, P., Celis, J. E., Nakamura, R. M. and Tan, E. M.: Monoclonal antitodies to a nuclear protein (PCNA/cyclin) associated with DNA replication. Exp. Cell. Res., 168: 475-486 (1987).

6) 坂田則行, 上田哲郎, 吉田洋二 : 冠状動脈硬化症 (総論). 病理と臨床, 4: 718-725 (1986).

7) Kajiya, F., Tsujioka, K., Ogasawara, Y., Wada, Y. and Matsuoka, T.: Analysis of flow characteristics in poststenotic regions of the human coronary artery during bypass graft surgery. Circulation, 76: 10921100 (1987).

8) Asakura, T. and Karino, T.: Flow patterns and spatial distribution of atherosclerotic lesions in human coronary arteries. Circ. Res., 66: 1045-1066 (1990).

9) Takahara, T., Kojima, T., Miyabayashi, C., Inove, K., Sasaki, H., Muragaki, Y. and Ooshima, A.: Collagen production in fat-storing cells after carbon tetrachloride intoxication in the rat immunoelectron microscopic observation of type I, type III collagens, and prolylhydroxylase. Lab. Invest., 59: 509-521 (1988).

10) Kato, M., Sawai, T. and Kyougoku, M.: Endoarterial proliferation and phenotype modulation of the vascular smooth muscle cell. In Proceeding of 3rd International Conference of Kawasaki Disease: 156-158 (1989).

11) Tsukada, T., Tippens, D., Gordon, D., Ross, R. and Gown, A. M.: HHF35 a muscle-actin-specific monoclonal antibody. I. Immunocytochemical and biochemical characterization. Am. J. Pathol., 126: 5160 (1987).

12) Celis, J. E. and Celis, A.: Cell cycle-dependent variations in the distribution of the nuclear protein cyclin/ proliferating cell nuclear antigen in cultured cells: subdivision of $\mathrm{S}$ phase. Proc. Natl. Acad. Sci., 82: 3262-3266 (1985).

13) Nakane, P. K., Moriuchi, T., Koji, T., Taniguchi, Y., Izumi, S. and Hui, L.: Proliferating cell nuclear antigen (PCNA/cyclin) review and some new findings. 
Acta Cytochem., 22: 105-116 (1989).

14) Wilcox, J. N., Smith, K. M., Williams, L. T., Schwartz, S. M. and Gordon, D.: Platelet-derived growth factor mRNA detection in human atherosclerotic plaques by in situ hybridization. J. Clin. Invest., 82: 1134-1143 (1988).

15) McCullagh, K. A. and Belian, G.: Collagen characterisation and cell transformation in human atherosclerosis. Nature, 258: 73-75 (1975).

16) Morton, L. F. and Barnes, M. J.: Collagen polymorphism in the normal and diseased blood vessel wall. Investigation of collagens types I, III and V. Atherosclerosis, 42: 41-51 (1982).

17) Ooshima, A.: Collagen $\alpha$ B chain: Increased propor- tion in human atherosclerosis. Science, 213: 666-668 (1981).

18) Ross, R. and Raines, E. W.: Platelet-derived growth factor-its role in health and disease. In Biology of Growth Factors. Molecular Biology, Oncogenes, Signal Transduction, and Clinical Implications (Kudlow, J. E., MacLennan, D. H., Bernstein, A. and Gotlieb, A. I. eds.), Plenum, New York, pp. 9-21 (1988).

19) 山根 徹: 血流と動脈硬化の局在化, 第90回日本医 学会シンポジウム, 動脈硬化' 90 —その発生要因・ 機構・進展一. 日本医学会, 東京：66-71 (1991).

20) 畑隆一郎：コラーゲン一その機能と代謝. 蛋白質・ 核酸・酵素, 31: 29-52 (1986)

\title{
Summary
}

\section{Role of Collagen Fibers and Intimal Smooth Muscle Cells in the Progression of Human Coronary Atherosclerosis}

\author{
Fumi IKedA*, Yoji YoshidA** and Koji TAMURA* \\ *Second Department of Internal Medicine, Yamanashi Medical College, Yamanashi, Japan \\ **First Department of Pathology, Yamanashi Medical College, Yamanashi, Japan
}

Diffuse intimal thickening (DIT) has developed in the human coronary artery even in infants. Eccentric intimal thickening (EIT) evolves from DIT and may develop into atheromatous plaque. The purpose of this study is to clarify histological changes in the intima during the development of DIT to EIT or plaque in the human coronary artery.

Materials for histometrical examination were obtained from 253 autopsy cases. Histometrical studies were carried out on the proximal portions of the right coronary artery (seg. 1) and the left anterior descending artery (seg. 6). Thicknesses of the intima and the media and the $\mathrm{I} / \mathrm{M}$ ratio were measured in all cases. In cases over 20 years of age, volume fractions ( $\mathrm{Vfs}$ ) of SMCs, collagen fibers, and elastic fibers in the intima were analyzed by the pointcounting method. The number and density of SMCs were counted within the same area. DIT in both segs. 1 and 6 tended to increase with age. The I/M ratio in DIT increased with age but did not exceed 2. EIT increased more markedly with age than did DIT. Collagen fibers were the major component of the intima. Vfs of collagen fibers increased with successive changes from DIT to EIT and finally to plaque in contrast to the decrease in the density of SMCs when compared within the same age groups.

In immunohistochemical studies, anti-muscle antigen (HHF35) positive SMCs were present in DIT as well as in EIT. A great number of anti-macrophage antigen positive foam cells were present in the plaque, particularly in plaque shoulder. Proliferating cell nuclear antigen (PCNA) positive cells were predominantly distributed in plaque shoulder, and prolyl hydroxylase $(\mathrm{PH})$ positive cells were present within the same area. Anti-collagen Type I antibody reacted intensely to fibers in plaque, but fibers which reacted with the anti-collagen Type III antibody were randomly distributed in every layer of the arterial wall.

In conclusion, DIT, EIT and plaque thickening in the coronary artery were chiefly due to SMC proliferation in the younger subjects; however, after the 4th decade, thickening was mainly due to an accumulation of collagen fibers.

Key words: Coronary artery, Histometrical study, Collagen accumulation, SMC proliferation, PCNA. 